\title{
Studies on Soil Nutrient Status in Relation to Quality Attributes of Sweet Orange (Citrus sinesis L.) Fruit Cv. Nucellar
}

\author{
S. M. Rathod ${ }^{1}$ and P. B. Sable ${ }^{2 *}$ \\ ${ }^{1}$ Department of Horticulture, RMA College of Agriculture, Navha, Jalna, Maharashtra, India \\ ${ }^{2}$ Department of Horticulture, Shri Shivaji Agriculture College, Amravati, 444602, \\ Maharashtra, India \\ *Corresponding author
}

\section{A B S T R A C T}

\section{Keywords}

Soil nutrient status, quality, sweet orange

Article Info

Accepted:

12 March 2021

Available Online:

10 April 2021
An experiment was conducted at College of Agriculture, Latur (M.S.), during summer and kharif season of 2014-15 to study the nutrient status of soils of sweet orange orchards of Jalna District. In order to know the soil nutrient status, ten sweet orange orchards located in ten different talukas of Jalna district were randomly selected. Soil samples were collected in May 2014 at a depth of $0-30 \mathrm{~cm}, 30-60 \mathrm{~cm}$ and $60-90 \mathrm{~cm}$. All the samples were in safe limit for electrical conductivity (EC). All soil samples were low to medium in organic carbon content $(\mathrm{OC})$, nitrogen content $(\mathrm{N})$, available phosphorus (P), sulphur contents $(\mathrm{S})$ and manganese content $(\mathrm{Mn})$. All soil samples were high in calcium content $(\mathrm{Ca})$, available magnesium content $(\mathrm{Mg})$. The soil were sufficient in available copper content $(\mathrm{Cu})$. Results also showed that there was positive significant correlation of $\mathrm{OC}, \mathrm{N}, \mathrm{P}, \mathrm{K}$, $\mathrm{Mg}$ and $\mathrm{Cu}$ with fruit quality parameters.

\section{Introduction}

Sweet orange (Citrus sinesis L.) belongs to family Rutaceae and originated in south China. It is grown in tropical and subtropical climate in the world for their sweet fruits, which can be eaten fresh or processed to obtain juice. In world the global production of oranges record 48.8 MMT (Anonymons, 2015). In India citrus grown in area of 846 thousand ha and the production of 7464 thousand MT with the productivity of 8.80 MT/ha (Anonymous, 2011). Maharashtra is the largest producer of sweet orange in the country and contributes to about $49 \%$ of the total production. Sweet orange is grown widely in different districts of Maharashtra but Jalna, Aurangabad, Nanded and Parbhani are the major area in production, among them Jalna is dominant in area and production. One 
of the main reasons for low sweet orange productivity in the soils of Marathwada region is multiple nutrient deficiencies. The soils of this region are derived from basaltic parent material and are deficient in nutrients including $\mathrm{N}, \mathrm{P}, \mathrm{Fe}, \mathrm{Mn}$ and $\mathrm{Zn}$. Therefore, above facts are essential to crate information about nutrient status of orchard soil so as to develop fertilizer schedule for sweet orange orchards of Jalna district. Considering the above facts the present investigation was made to study soil nutrient status in relation to quality of sweet orange to find out the relation between nutrient status and quality.

\section{Materials and Methods}

An experiment was carried out during summer 2014-15 at ten sweet orange orchards located in different talukas of Jalna district during year 2014-15. Soils of Jalna district ranges from deep black, shallow and light textured. Majority of soils are medium to deep black and categorized under order verti-sols and incepti-sols. In order to know the soil and leaf nutrient status, ten sweet orange orchards located in ten different talukas of Jalna district were randomly selected. The soil samples were collected in May 2014. The details of selected sweet orange orchards of Jalna district are given in Table 1.

These soil samples were collected from each orchard during May 2014 below the tree canopy of 0-30, 30-60 and 60-90cm depth. So in all 30 samples were collected within tree canopy of $0.5 \mathrm{~m}$ away from the tree trunk. Collected soil samples were brought to laboratory and dried under shade. After drying a part of each sample was ground by wooden mortar and pestle and stored in polythene bags with proper labeling for subsequent estimation of physicochemical characteristics, macronutrients and micronutrient. Soil $\mathrm{pH}$ was determined from (1:2:5) soil water suspension ratios using digital $\mathrm{pH}$ meter (Jackson, M. L.,
1973). Electrical conductivity (EC) was determined in suspension solution of soil water suspension $(1: 2: 5)$ using digital direct read conductivity bridge (Jackwon, M.L., 1973) and expressed in $\mathrm{dsm}^{-1}$. Available nitrogen was determined by Alkaline permanganate method as described by (Subhhia B.V. and Asija G.L. (1956). Available phosphorous was determined using double beam US-VIS spectrophotometer with (Olsen S.R. and et al., 1954). Available K was determined using Flame photometer (Jackson, M.L. 1967). Exchangeable $\mathrm{Ca}$ and $\mathrm{Mg}$ were determined by Versanate Titration method (Jackson, M.L. 1979). Available sulphur was determined by using 1:5 soil and extracted $0.15 \% \quad \mathrm{CaCl}_{2}$ solution on UVSpectrophotometer at $340 \mathrm{~nm}$ wavelength (Willians C.H. and Steinberg, A. 1959). Available micronutrients such as $\mathrm{Mn}, \mathrm{Zn}, \mathrm{Cu}$ were measured using atomic absorption spectrophotometer fro Perkins Elmer as described by Lindsay, W.L. and Norwell W.A. The twelve uniform matured fruits were collected from each orchard during November-December 2014. Washed 2-3 times with fresh water and brought to laboratory for analysis.

The weight of five fruits was recorded with the help of digital weight balance and averages were recorded as weight of fruit. The horizontal size of fruit was recorded with the help of vernier caliper and from that, total size of fruit recorded. Juice and seeds was separately weighed on digital balance and the ratio was calculated by dividing the juice weight, by weight of the seed. Total soluble solids (TSS) in terms of percent of juice were recorded by using Erma hand refractometer.

The total titrable activity was determined by titrating fruit juice against $0.1 \mathrm{NaOH}$ in the presence of phenolphthalein indicator (A.O.A.C., 1975) and computed percent acidity. Total sugar was calculated by using 
formula Total sugar $=$ Reducing sugar $(\%)+$ Non reducing sugar (\%). The trimetric method of Lane and Eynon as described by Rangana (1986) was followed for estimation of reducing sugar. The correlation between soil nutrient status and fruit quality parameters was worked out as per the standard given by Panse and Sukhatme, (1967).

\section{Results and Discussion}

\section{Physicochemical properties}

\section{Soil reaction $(\mathbf{p H})$}

Data from Table 2 clearly indicates that at 60$90 \mathrm{~cm}$ depth, the $\mathrm{pH}$ of soils was varied from 7.14-8.0 with an average value of 7.55. The lowest value (7.14) was observed in sample JS006 whereas higher value (8.0) was observed in sample JS004 in Table 1.

Thus, the soils were neutral to alkaline in reaction. The slightly alkaline $\mathrm{pH}$ of soils recorded in the study may he slightly alkaline $\mathrm{pH}$ of soils recorded in the study may describe to calcareous nature of these soils. The results were in agreement with Panchhabhai, D.M. and et al., (2006) in acid lime. They served 70 acid lime orchards in western Vidharbha region of Maharashtra and reported similar range of soil $\mathrm{pH}$ ranging from 7.9 to 8.3.

\section{Electrical Conductivity $\left(\mathrm{dsm}^{-1}\right)$}

Data from Table 2 clearly indicates that at 60$90 \mathrm{~cm}$ soil depth electrical conductivity varied from 0.15 to 0.28 with an average value of $0.22 \mathrm{dsm}^{-1}$. The lowest $\left(0.15 \mathrm{dsm}^{-1}\right) \mathrm{EC}$ was observed in sample JS009 in Table 2. Thus all sample were in safe limit. Above findings are in close conformity with the findings of Reddy et al., (2013) in Nagpur mandarin. They reported that range of EC $0.11-0.38 \mathrm{dsm}^{-1}$ in Nagpur mandarin orchards of Soner Tehsil, Nagpur district of Maharashtra.

\section{Organic Carbon Content}

Data from Table 2 clearly indicate that at 60$90 \mathrm{~cm}$ depth, soil organic carbon content was varied from 0.19 to 0.46 percent with an average value of 0.32 percent. The lowest organic carbon content (0.19 percent) was observed in sample JS002. Whereas highest organic carbon content (0.46 percent) was recorded in sample JS009 in Table 2. Thus soils were low to medium in organic carbon content. The result of the present findings were in agreement with Kumar et al., (2011) in Kinnow mandarin. They observed that organic carbon content in soils were found in range from 0.26 to 0.46 percent in Kinnow mandarin.

\section{Available Nitrogen}

Data from Table 2 indicates that at $60-90 \mathrm{~cm}$ depth, available nitrogen in soil was varied from 103.9 to $245.1 \mathrm{~kg} \mathrm{ha}^{-1}$ with an average value of $185.52 \mathrm{~kg} \mathrm{ha}^{-1}$. The lowest $\mathrm{N}$ (103.9) was observed in sample JS008. Whereas highest $\mathrm{N}\left(245.1 \mathrm{~kg} \mathrm{ha}^{-1}\right)$ was recorded in sample JS006. Similar results were observed by Reddy et al., (2013) in Nagpur mandarin. They reported that available nitrogen in soil of Nagpur mandarin orchards in range of 38 to $225 \mathrm{~kg} \mathrm{ha}^{-1}$. Thus, all the sample were low to medium in nitrogen content.

\section{Available Phosphorus}

Data from Table 2 clearly indicates that at 60$90 \mathrm{~cm}$ depth, available phosphorus in soil was varied from 6.20 to $11.16 \mathrm{~kg} \mathrm{ha}^{-1}$ with an average value of $8.84 \mathrm{~kg} \mathrm{ha}^{-1}$.

The lowest $\mathrm{P}\left(6.20 \mathrm{~kg} \mathrm{ha}^{-1}\right)$ was recorded in sample JS0010. Whereas, highest P $(11.16 \mathrm{~kg}$ $\mathrm{ha}^{-1}$ ) was recorded in sample JS009. Thus, all samples were low to medium in available phosphorous. The results were in line with the findings of Reddy et al., (2013) in Nagpur 
mandarin orchard soil. They reported that available $\mathrm{P}$ ranging from $10-22 \mathrm{~kg} \mathrm{ha}^{-1}$ in mandarin orchard soils of Saoner Tahsil or Nagpur district.

\section{Available Potassium}

It is evident from the data presented in Table 2 that at $60-90 \mathrm{~cm}$ depth available potassium in soil varied from 320.1 to $405.2 \mathrm{~kg} \mathrm{ha}^{-1}$ with an average value of $373.39 \mathrm{~kg} \mathrm{ha}^{-1}$. The lowest $\left(320.1 \mathrm{~kg} \mathrm{ha}^{-1}\right)$ was observed in sample JS008.

Thus all samples were high in available $\mathrm{K}$. The results were in accordance with the findings of Reddy et al., (2013) in mandarin orchards. They reported that $\mathrm{K}$ ranges from 48 to $385 \mathrm{~kg} \mathrm{ha}^{-1}$ in soils of mandarin orchards of Nagpur district.

\section{Available Calcium}

Data from Table 2 clearly indicated that at 60 $90 \mathrm{~cm}$ depth available calcium contents varied from 2.98 to $4.87 \mathrm{me}^{100 \mathrm{~g}^{-1}}$ with an average value $4.18 \mathrm{me}^{100 \mathrm{~g}^{-1}}$. The lowest value $(4.87$ me $100 \mathrm{~g}^{-1}$ ) was recorded in sample JS006.

Thus, all soils were high in calcium contents. Similar results reported by Reddy et al., (2013) in citrus orchard. They observed that, the range of a Ca from 5.6 to $39.2 \mathrm{me}^{100 \mathrm{~g}^{-1}}$ in citrus orchards of Sahiwal district.

\section{Available Magnesium}

Data from Table 2 clearly indicated that at 60 $90 \mathrm{~cm}$ depth, available magnesium content varied from 2.46 to 3.64 with an average value 4.81. The lowest value (2.46) was observed in sample JS006. Whereas, the highest value (3.64) was recorded in sample JS009. Thus, the soils were high in magnesium content. Similar results were reported by Panchabhai $e t$ al., (2006) in acid lime orchards in Western Vidarbha.

\section{Available Sulphur}

The data on available sulphur in Table 2 indicated that at $60-90 \mathrm{~cm}$ depth, it was varied from 4.00 to $5.59 \mathrm{mg} \mathrm{kg}^{-1}$ with an average value $4.81 \mathrm{mg} \mathrm{kg}^{-1}$. The lowest value $(4.00 \mathrm{mg}$ $\mathrm{kg}^{-1}$ ) was observed in sample JS008. Whereas, highest value $\left(5.59 \mathrm{mg} \mathrm{kg}^{-1}\right)$ was recorded in sample JS009. Thus, the soils were low to medium in sulphur content. Similar result was observed by Parwe S.K. (2013) in Pomegranate, the orchards of South-East region in Beed district in Maharashtra.

Table.1 Details of selected sweet orange orchards of Jalna district

\begin{tabular}{|c|c|c|c|c|}
\hline $\begin{array}{c}\text { Sr. } \\
\text { No }\end{array}$ & $\begin{array}{c}\text { Sample } \\
\text { No. }\end{array}$ & Name of cultivator & $\begin{array}{c}\text { Name of } \\
\text { Tahsil }\end{array}$ & Name of village \\
\hline $\mathbf{1}$ & JS001 & Laxman T. Kachare & Jalna & Kacharewadi \\
\hline $\mathbf{2}$ & JS002 & Balaji N. Kachare & Jalna & Kacharewadi \\
\hline $\mathbf{3}$ & JS003 & Sandeep T. Kolhe & Badnapur & Deogaon \\
\hline $\mathbf{4}$ & JS004 & Haribhau B. Ghate & Jalna & Dukri Pimpri \\
\hline $\mathbf{5}$ & JS005 & Abhay A. Shendre & Ambad & Pimpalgaon \\
\hline $\mathbf{6}$ & JS006 & Vilas B. Kharat & Ambad & Dhangar Pimpari \\
\hline $\mathbf{7}$ & JS007 & Bhimrao R. Pund & Ambad & Pimpalgaon \\
\hline $\mathbf{8}$ & JS008 & Sanjay S. Shere & Mantha & Waturphata \\
\hline $\mathbf{9}$ & JS009 & Dnyaneshwar B. Dahatonde & Ghansawangi & Talegaon \\
\hline $\mathbf{1 0}$ & JS0010 & Vinod B. Mahajan & Ghansawangi & Talegaon \\
\hline
\end{tabular}


Table.2 Physico-chemical characteristics and soil nutrient status of sweet orange orchards of Jalna district at $60-90 \mathrm{~cm}$ dept

\begin{tabular}{|c|c|c|c|c|c|c|c|c|c|c|c|c|}
\hline $\begin{array}{c}\text { Sample } \\
\text { No. }\end{array}$ & pH & $\begin{array}{c}\mathrm{EC} \\
\mathrm{dsm}^{-}\end{array}$ & $\begin{array}{c}\text { Organic } \\
\text { carbon } \\
(\%)\end{array}$ & $\begin{array}{c}\text { Nitrogen } \\
\text { kg ha }^{-1}\end{array}$ & $\begin{array}{c}\text { Phosphorus } \\
\text { kg ha }^{-1}\end{array}$ & $\begin{array}{l}\text { Potassium } \\
\text { kg ha }^{-1}\end{array}$ & $\begin{array}{c}\text { Calcium } \\
\mathrm{mg}^{-1} \\
\mathbf{1 0 0 g}^{-1}\end{array}$ & $\begin{array}{c}\text { Magnesium } \\
{\mathrm{mg} 100 \mathrm{~g}^{-1}}^{-}\end{array}$ & $\begin{array}{c}\text { Sulphur } \\
\text { mg kg }^{-1}\end{array}$ & $\begin{array}{c}\text { Mangnese } \\
\mathrm{mg} \mathrm{kg}^{-1}\end{array}$ & $\begin{array}{c}\text { Zinc } \\
\mathbf{m g} \\
\mathbf{k g}^{-1}\end{array}$ & $\begin{array}{l}\text { Copper } \\
\text { mg kg }^{-1}\end{array}$ \\
\hline JS001 & 7.62 & 0.17 & 0.38 & 227.3 & 10.28 & $401-2$ & 8.73 & 3.11 & 5.3 & 1.20 & 0.41 & 2.13 \\
\hline JS002 & 7.59 & 0.24 & 0.19 & 134.9 & 9.30 & 400.4 & 4.26 & 3.17 & 4.10 & 1.10 & 0.40 & 1.28 \\
\hline JS003 & 7.41 & 0.26 & 0.37 & 205.0 & 9.43 & 357.6 & 2.98 & 2.89 & 5.03 & 1.11 & 0.48 & 1.10 \\
\hline JS004 & 8.0 & 0.23 & 0.23 & 142.5 & 8.24 & 320.1 & 4.16 & 3.34 & 5.0 & 1.93 & 0.46 & 1.51 \\
\hline JS005 & 7.96 & 0.22 & 0.24 & 147.0 & 8.20 & 331.4 & 4.63 & 2.70 & 5.35 & 1.0 & 0.43 & 1.17 \\
\hline JS006 & 7.14 & 0.21 & 0.44 & 245.1 & 9.70 & 367.6 & 4.87 & 2.46 & 5.39 & 2.23 & 0.32 & 2.16 \\
\hline JS007 & 7.58 & 0.27 & 0.42 & 227.3 & 9.62 & 391.3 & 4.32 & 2.51 & 5.59 & 1.26 & 0.38 & 1.39 \\
\hline JS008 & 7.69 & 0.15 & 0.31 & 103.9 & 6.27 & 405.2 & 4.48 & 2.69 & 4.0 & 1.12 & 0.42 & 1.73 \\
\hline JS009 & 7.19 & 0.28 & 0.46 & 243.6 & 11.16 & 402.7 & 4.55 & 3.64 & 4.25 & 1.52 & 0.40 & 2.21 \\
\hline JS0010 & 7.34 & 0.19 & 0.21 & 178.6 & 6.20 & 356.4 & 3.87 & 2.68 & 4.11 & 2.24 & 0.37 & 1.37 \\
\hline Range & $\begin{array}{c}7.14- \\
8.0\end{array}$ & $\begin{array}{c}0.15- \\
0.28\end{array}$ & $\begin{array}{c}0.19- \\
0.46\end{array}$ & $\begin{array}{l}103.9- \\
245.1\end{array}$ & $6.20-11.16$ & $\begin{array}{c}320.1- \\
405.2\end{array}$ & $\begin{array}{c}2.98- \\
4.87\end{array}$ & $2.46-3.64$ & $4.0-5.59$ & $1.0-224$ & $\begin{array}{c}0.32- \\
0.48\end{array}$ & $\begin{array}{l}1.10- \\
2.21\end{array}$ \\
\hline Mean & 7.55 & 0.22 & 0.32 & 185.52 & 8.84 & 373.39 & 4.18 & 2.91 & 4.81 & 1.47 & 0.40 & 1.59 \\
\hline $\mathrm{SE} \pm$ & 0.092 & 0.014 & 0.032 & 13.433 & 0.513 & 9.927 & 0.172 & 0.122 & 0.198 & 0.153 & 0.014 & 0.144 \\
\hline
\end{tabular}


Table.3 Fruit quality parameters of different sweet orange orchards.

\begin{tabular}{|c|c|c|c|c|c|c|c|}
\hline Sample No. & $\begin{array}{l}\text { Weight of } \\
\text { Fruit (g) }\end{array}$ & $\begin{array}{l}\text { Size } \\
(\mathrm{cm})\end{array}$ & $\begin{array}{c}\text { Juice : Seed } \\
\text { ratio }\end{array}$ & $\begin{array}{l}\text { TSS } \\
(\%)\end{array}$ & $\begin{array}{c}\text { Acidity } \\
(\%)\end{array}$ & $\begin{array}{c}\text { Reducing } \\
\text { Sugar (\%) }\end{array}$ & $\begin{array}{c}\text { Total } \\
\text { Sugar }(\%)\end{array}$ \\
\hline JS001 & 243.50 & 7.80 & 21.68 & 9.5 & 0.57 & 1.52 & 9.65 \\
\hline JS002 & 236.80 & 7.70 & 21.31 & 9.2 & 0.56 & 1.55 & 9.62 \\
\hline JS003 & 241.77 & 7.80 & 21.27 & 9.1 & 0.56 & 1.53 & 9.62 \\
\hline JS004 & 235.00 & 7.20 & 19.48 & 9.0 & 0.55 & 1.50 & 9.60 \\
\hline JS005 & 240.13 & 7.30 & 21.03 & 9.2 & 0.56 & 1.51 & 9.89 \\
\hline JS006 & 245.53 & 7.90 & 21.46 & 9.6 & 0.57 & 1.54 & 9.68 \\
\hline JS007 & 238.12 & 7.70 & 21.61 & 9.2 & 0.55 & 1.52 & 9.63 \\
\hline JS008 & 235.12 & 7.60 & 21.34 & 9.4 & 0.56 & 1.53 & 9.61 \\
\hline JS009 & 250.80 & 8.10 & 21.65 & 9.8 & 0.58 & 1.57 & 9.74 \\
\hline JS0010 & 242.16 & 7.50 & 20.71 & 9.5 & 0.56 & 1.48 & 9.57 \\
\hline $\mathrm{SE} \pm$ & 1.57 & 0.08 & 0.20 & 0.008 & 0.003 & 0.008 & 0.029 \\
\hline C Dat $5 \%$ & 4.73 & 0.25 & 0.62 & 0.025 & 0.009 & 0.024 & 0.089 \\
\hline CV \% & 2.06 & 3.54 & 3.11 & 2.68 & 1.63 & 1.67 & 0.96 \\
\hline
\end{tabular}

Table.4 Correlation coefficient (r) between soil nutrient status and fruit quality parameters

\begin{tabular}{|c|c|c|c|c|c|c|c|}
\hline Soil Nutrients & $\begin{array}{l}\text { Weight of } \\
\text { Fruit (g) }\end{array}$ & $\begin{array}{l}\text { Size } \\
(\mathrm{cm})\end{array}$ & $\begin{array}{c}\text { Juice :Seed } \\
\text { Ratio }\end{array}$ & $\begin{array}{l}\text { TSS } \\
(\%)\end{array}$ & $\begin{array}{c}\text { Acidity } \\
(\%)\end{array}$ & $\begin{array}{l}\text { Reducing } \\
\text { Sugar (\%) }\end{array}$ & $\begin{array}{c}\text { Total } \\
\text { Sugar }(\%)\end{array}$ \\
\hline pH & -0.685 & -0.796 & -0.584 & -0.668 & -0.588 & -0.416 & 0.159 \\
\hline EC & 0.272 & 0.192 & 0.266 & -0.089 & -0.027 & 0.263 & $0.538 *$ \\
\hline OC & $0.697 * *$ & $0.912 * *$ & $0.756^{* *}$ & $0.680 * *$ & $0.584 * *$ & $0.583 * *$ & -0.044 \\
\hline $\mathbf{N}$ & $0.660 * *$ & $0.894 * *$ & $0774 * *$ & $0.657 * *$ & $0557 * *$ & $0.516^{*}$ & -0.084 \\
\hline $\mathbf{P}$ & $0.737 * *$ & $0.780 * *$ & $0570 * *$ & $0.525 * *$ & $0.725 * *$ & 0.227 & 0.303 \\
\hline $\mathbf{K}$ & 0.184 & $0.687 * *$ & $0.794 * *$ & 0.383 & $0.445^{*}$ & $0.773 * *$ & 0.054 \\
\hline $\mathrm{Ca}$ & 0.192 & 0.157 & 0.260 & $0.517^{*}$ & 0.390 & 0.349 & 0.448 \\
\hline Mg & $0.472 * *$ & 0.249 & -0.067 & 0.326 & $0.506^{*}$ & $0.532 *$ & 0.393 \\
\hline $\mathbf{S}$ & 0.267 & 0.138 & 0.395 & 0.109 & -0.017 & -0.305 & 0.170 \\
\hline Mn & 0.328 & 0.0096 & -0.248 & 0.400 & 0.220 & 0.383 & -0.273 \\
\hline Zn & -0.352 & -0.647 & -0.464 & -0.579 & -0.374 & -0.560 & 0.224 \\
\hline $\mathrm{Cu}$ & $0.586 * *$ & $0.581 *$ & 0.335 & $0.793 * *$ & $0.745^{* *}$ & $0.449 *$ & 0.043 \\
\hline
\end{tabular}

Abbreviations * $=$ Significant at $5 \%$ level, $* *$-Significant at $1 \%$ level. 


\section{Available Manganese}

The data on available manganese in soil in Table 2 indicated that at $60-90 \mathrm{~cm}$ depth, it was varied from 1.00 to $2.24 \mathrm{mgkg}^{-1}$ with an average value $1.47 \mathrm{mg} \mathrm{kg}^{-1}$. The lowest value $\left(1.00 \mathrm{mgkg}^{-1}\right)$ was observed in sample JS0010.

Thus, the soils were low to medium in manganese content. The similar trend reported in soils from Maharashtra by Kazi et al., (2012) in Sweet orange orchard.

\section{Available zinc}

The data on available zinc in soil in Table 2 indicated that at $60-90 \mathrm{~cm}$ depth, it was varied from 0.32 to $0.48 \mathrm{mg} \mathrm{kg}^{-1}$ with an average value $0.40 \mathrm{mg} \mathrm{kg}^{-1}$. The lowest value $(0.32 \mathrm{mg}$ $\mathrm{kg}^{-1}$ ) was observed in sample JS006. Whereas, the highest value $\left(0.48 \mathrm{mg} \mathrm{kg}^{-1}\right)$ was recorded in sample JS003. Similar results were observed by Khokhar et al., (2012) in Kinnow orchards gown in aridisols of Punjab, India.

\section{Available copper}

The data on available copper in soil in Table 2 , indicated that at $60-90 \mathrm{~cm}$ depth, it was varied from 1.10 to $2.21 \mathrm{mg} \mathrm{kg}^{-1}$ within average value $1.59 \mathrm{mg} \mathrm{kg}^{-1}$. The lowest value (1.10 $\mathrm{mg} \mathrm{kg}^{-1}$ ) was observed in sample JS001.

Thus the soils were sufficient in available copper content. Such type of trend was also observed in soil samples reported by Rane et al., (2010) in micro-propaged banana orchards of Maharashtra.

\section{Quality Attributes}

\section{Weight of fruit}

It is revealed from the data presented in Table 3 that highest weight of fruit was recorded in sample JS009 (250.80g) while, the lowest weight of fruit was recorded in sample JS004 $(235.12 \mathrm{~g})$. These results are in conformity with Karla et al., (1989).

\section{Size of fruit}

The data recorded in Table 3 indicated that highest size of fruit was recorded in sample JS009 $(8.10 \mathrm{~cm})$ and lowest in JS004 $(7.20 \mathrm{~cm})$. The variation in fruit size could be attributed due to availability of nutrients and number of fruits on the tree. Karla et al., (1989) reported highest size of fruit $(7.50 \mathrm{~cm})$ in Valencia late, while the lowest in Blood red $(6.83 \mathrm{~cm})$.

\section{Juice : Seed ratio}

The data recorded in Table 3 indicated that the highest juice : seed ratio was recorded in sample JS001 (21.68), followed by sample JS009 (21.65). The lowest juice : seed ratio (19.48) was observed in sample JS004. These results are also in conformity with Verma et al., (2012).

\section{Total soluble solids (\%)}

It is revealed from the data presented in Table 3 that the highest TSS was recorded in sample JS009 (9.8\%) followed by sample JS006 $(9.6 \%)$. These results are in conformity with Verma et al., (2012) reported $10.04 \%$ TSS in Nagpur mandarin.

\section{Acidity (\%)}

It is revealed from the data presented in Table 3 that, there were no significant difference in all the sample tested. The maximum acidity $(0.58 \%)$ was recorded in sample JS009 followed by JS001, JS006 (0.57\%). The minimum acidity was recorded in sample JS004 and JS007 (0.55\%). Similar results found by Karla et al., (1989) reported the range 0.32 to $0.97 \%$ in six cultivars of sweet orange in orchards of Punjab. 


\section{Reducing Sugar (\%)}

The data recorded in Table 3 indicated that the highest reducing sugar was observed in sample JS009 (1.57\%), followed by JS002. The minimum reducing sugar $(1.48 \%)$ was recorded in sample JS0010. These results are in conformity with Kazi et al., (2012) found range of reducing sugar content from 1.6 to 2.3 in sweet orange.

\section{Total sugar (\%)}

From the data presented in Table 3, it was revealed that, there were significant differences observed in all the samples studied. The maximum total sugar $(9.89 \%)$ was recorded in sample JS005, whereas minimum reducing sugar $(9.57 \%)$ was recorded in sample JS0010. Similar results were found by Kazi et al., (2012).

\section{Correlation coefficient between soil nutrient status with fruit quality}

Data from Table 4 showed that, there was positive significant correlation of $\mathrm{OC}, \mathrm{N}, \mathrm{P}, \mathrm{K}$, $\mathrm{Mg}$ and $\mathrm{Cu}$ with the fruit quality parameters. $\mathrm{Ca}$ had significant positively correlated with TSS and acidity. Mg had significant positive correlation with weight of fruits, reducing sugar except juice seed ratio, it had negative correlation. It had positively correlated with all quality parameters except acidity and reducing sugar. Mn had positively correlated with quality parameters except juice : seed ration and total sugar had negative correlation. ' $\mathrm{pH}$ ' and ' $\mathrm{Zn}$ ' were negatively correlated with all fruit quality parameters except total sugar it had positive correlation

All the samples were in safe limit for electrical conductivity (EC). All soil samples were low to medium in organic carbon content (OC), nitrogen content $(\mathrm{N})$, available phosphorus $(\mathrm{P})$, sulphur contents (S) and manganese content $(\mathrm{Mn})$. All soil samples were high in calcium content $(\mathrm{Ca})$, available magnesium content $(\mathrm{Mg})$. The soil were sufficient in available copper content $(\mathrm{Cu})$. Results also showed that there was positive significant correlation of $\mathrm{OC}, \mathrm{N}, \mathrm{P}, \mathrm{K}, \mathrm{Mg}$ and $\mathrm{Cu}$ with fruit quality parameters

\section{References}

Anonymous, 2011. National Horticulture Board, Advance Estimate of the year, Govt. of India.

Anonymous, 2015. Citrus world market and trade, United States Department of Agriculture, Foreign Agriculture Service.

Jackson M. L 1967. Soil chemical analysis. Prentice Hall of India Pvt. Ltd., New Delhi. PP:205.

Jackson M. L. 1973. Soil chemical analysis. Prentice Hall of India Pvt. Ltd., New Delhi. PP : 498.

Jackson M. L. 1979. Soil chemical analysisAdvanced Course, $2^{\text {nd }}$ Edn. Publ. by the author, Uni. of Wisconsin, Madison, USA.

Karla, S. K., J. N Sharma and G. S. Chohan 1989. Tree growth, yield and fruity quality of six sweet orange (Citrus sinensis $C$.).

Kazi, S. S., S. Ismail and K. G. Joshi 2012. Effect of multi-micronutrient on yield and quality attributes of sweet orange. African Journal of Agriculture Research, 7(29) 4118-4123.

Khokar Y., H. R. Singh, W. D. Singh, G. Singh and P. G. Singh 2012. Soil fertility and nutritional status of Kinnow orchards grown in aridisol of Punjab, India. African Journal of Agriculture Research, 7(33) : 46924697.

Kumar, P., S. Sharma, S. S. Dhankar and P. P. Singh 2011. Studies on Kinnow (Citrus reticulata Blanco) decline in 
relation to soil plant nutritional status. Not Sci.Biol., 3(3) : 109-112.

Olsen, S. R., C. V. Cole, F. S. Watanbe and L. A. Dean 1954. Estimation of available phosphorus in soil by extraction with sodium bicarbonate. VS-Department of Agriculture Circular. PP : 99.

Panchbhai, D. M., V. K. Mohorkar, N. D. Jogdande, M. N. Patil and R. N. Katkar 2006. Studies in soil nutrient status of acid lime orchards in western Vidarbha. Internat J. Agric. Sci.,(2) : 573-576.

Panse V.G. and P. N. Sukhatme 1967. Statistical methods for agricultural workers. IARI, New Delhi.

Parve, S.K. 2013. Nutritional evaluation of pomegranate orchards of South East region in Beed district of Maharashtra. M. Sc. (Agri.). Thesis submitted to VNMKV, Parbhani.

Rane, M. M., H. K. Kausadikar and R. S. Manekar 2010. Micronutrient Status of Micropropagated Banana (Musa paradisica L.) orchards of Marathwada, An Asian Journal of Soil
Science, 5. (1) : 103-105.

Rangana, 1986. Hand book of analysis and quality control for fruits and vegetables.

Reddy, C.B., V.D. Guldekar and N. Balakrishnan 2013. Infthhence of soil calcium carbonate on yield and quality of Nagpur mandarin. Indian Journal of Horticulture, 60(2) : 121-126.

Reddy, Y. T. N., R. M. Kurian, N. T. Sujatha and M. Srinivas 2003. Leaf and Soil nutrient status in relation to yield of Mango. Indian Journal of Horticulture, 60(2) : 121-126.

Subhhia B. V. and Asija G. L. 1956. Curr.Sci., 25, 259-260.

Verma, S. and P. Bhatnagar 2013. Plant tissue analysis of Nagpur mandarin (Citrus reticulata Blanco) orchard in Jhalawar district of Rajasthan. International J. of Agric. Sciences (9).

Williams, C.H. and A. Steinberg 1959. Soil sulphur fractions as chemical indices of available sulphur in some Australian soils. Aust. J. Agric. Res., 10 : 217-22.

\section{How to cite this article:}

Rathod, S. M. and Sable, P. B. 2021. Studies on Soil Nutrient Status in Relation to Quality Attributes of Sweet Orange (Citrus sinesis L.) Fruit Cv. Nucellar. Int.J.Curr.Microbiol.App.Sci. 10(04): 57-65. doi: https://doi.org/10.20546/ijcmas.2021.1004.007 